\title{
SUNNHEMP AND MILLET AS GREEN MANURE FOR TROPICAL MAIZE PRODUCTION
}

\author{
Adriano Perin ${ }^{1}$; Ricardo Henrique Silva Santos ${ }^{1 *}$; Segundo Sacramento Urquiaga ${ }^{2}$; Paulo \\ Roberto Cecon ${ }^{3}$; José Guilherme Marinho Guerra²; Gilberto Bernardo de Freitas ${ }^{1}$ \\ ${ }^{1}$ UFV - Depto. de Fitotecnia, Av. P.H. Rolfs, s/n. - Campos Universitário - 36570-000 - Viçosa, MG - Brasil. \\ ${ }^{2}$ Embrapa Agrobiologia, C.P. 74505 - 23890-000 - Seropédica, RJ - Brasil. \\ ${ }^{3} U F V$ - Depto. de Informática. \\ *Corresponding author <rsantos@ufv.br>
}

ABSTRACT: Commonly N release from legume residues is rapid in the tropics. Legume mixtures with grasses can result in slower nutrient release from residues, better matching the $\mathrm{N}$ requirements of the following crop. The objectives of this study were to evaluate the effects of the green manures sunnhemp (Crotalaria juncea) and millet (Pennisetum glaucum), alone or mixed, on the performance of a subsequent maize crop with and without the application of $\mathrm{N}$-fertilizer. The experiment consisted of four randomized blocks, with split plots. The plot treatments consisted of previous cultivation of sunnhemp, millet, mixed sunnhemp+millet and weeds. The subplot treatments were $90 \mathrm{~kg} \mathrm{~N} \mathrm{ha}^{-1}$ and absence of $\mathrm{N}$-fertilizer. Substantial amounts of biological nitrogen fixation (BNF) nitrogen were present in above ground parts of sunnhemp alone (173 kg ha-1) and mixed with millet $\left(89 \mathrm{~kg} \mathrm{ha}^{-1}\right)$. Decay rates showed that half of the $\mathrm{N}$ was released 15 and 22 days from sunnhemp and sunnhemp+millet residues, respectively. The difference was attributed to temporary immobilization due to the higher $\mathrm{C} / \mathrm{N}$ ratio of sunnhemp + millet. The preceding sunnhemp + millet treatment resulted in a larger maize yield than sunnhemp alone, when no $\mathrm{N}$-fertilizer was applied. This effect was not observed when $\mathrm{N}$-fertilizer was added. This effect may be due to a more timely $\mathrm{N}$ release, compared to sunnhemp and millet alone, when available $\mathrm{N}$ is required for maize. Nitrogen budgets showed that $15 \%$ and $10 \%$ in maize grain $\mathrm{N}$ was recovered from BNF for sunnhemp alone and sunnhemp + millet respectively. The recovery of $\mathrm{N}-\mathrm{BNF}$ by maize was $65 \%$ higher after sunnhemp + millet than after sunnhemp monocrop.

Key words: $\mathrm{N}$ recovery, biological nitrogen fixation, decomposition rate, intercropping

\section{CROTALÁRIAE MILHETO COMOADUBOS VERDES PARA A PRODUÇÃO DE MILHO NOS TRÓPICOS}

RESUMO: A liberação de nutrientes dos resíduos de leguminosas é rápida nos trópicos. A consorciação com gramíneas pode resultar em liberação de nutrientes desses resíduos mais lenta e adequada aos requerimentos de $\mathrm{N}$ da cultura subseqüente. Os objetivos do trabalho foram avaliar os efeitos dos adubos verdes crotalária (Crotalaria juncea) e milheto (Pennisetum glaucum), solteiros ou consorciados, sobre o desempenho do milho com ou sem a aplicação de N-fertilizante. $\mathrm{O}$ experimento foi instalado em quatro blocos casualizados em parcelas subdivididas. Os tratamentos da parcela consistiram do cultivo prévio de crotalária, milheto, crotalária+milheto e ervas. Os tratamentos da subparcela foram $90 \mathrm{~kg} \mathrm{~N} \mathrm{ha}^{-1}$ e ausência de $\mathrm{N}$-fertilizante. A parte aérea da crotalária solteira ou consorciada apresentou, respectivamente, $173 \mathrm{~kg} \mathrm{ha}^{-1}$ e $89 \mathrm{~kg} \mathrm{ha}^{-1}$ de FBN-N. Metade do $\mathrm{N}$ foi liberado em 15 e 22 dias, dos resíduos de crotalária solteira e crotalária+milheto respectivamente. Esta diferença foi provavelmente causada pela imobilização temporária devido à maior $\mathrm{C} / \mathrm{N}$ da crotalária+milheto. Na ausência de $\mathrm{N}$-fertilizante o cultivo prévio de crotalária+milheto resultou em maior produtividade do milho que a crotalária solteira. Esse resultado não se repetiu com a aplicação de N-fertilizante. Esse efeito é atribuído à liberação de $\mathrm{N}$ mais sincronizada com o requerimento do milho do que com crotalária e milheto solteiros. $\mathrm{O}$ balanço de nitrogênio mostra que a recuperação de N-FBN foi de $15 \%$ e $10 \%$ do $\mathrm{N}$ nos grão de milho após crotalária solteira e crotalária+milheto respectivamente. A utilização de N-FBN pelo milho foi $65 \%$ maior após crotalária+milheto do que após crotalária solteira.

Palavras-chave: recuperação de nitrogênio, fixação biológica do nitrogênio, taxa de decomposição, consórcio 


\section{INTRODUCTION}

Despite the low average yield $(3,400 \mathrm{~kg}$ ha1), maize is responsible for the largest removal of $\mathrm{N}$ by a single crop species in Brazilian agriculture, with an annual total withdrawal of approximately 740 thousand tons of $\mathrm{N}$ contained in harvested grain. Rotation with leguminous green manure can result in significant inputs of nitrogen into the soil-plant system and subsequent crops (Boddey et al., 1997; Fillery, 2001; Ramos et al., 2001; Cobo et al., 2002b). N mineralization rate from leguminous residues can be very high under tropical conditions (Tian et al., 1992; Cobo et al., 2002a). High $\mathrm{N}$ immobilization or losses through leaching (Fillery, 2001) and or volatilization (Janzen \& McGinn, 1991) can occur if $\mathrm{N}$ is released when crop $\mathrm{N}$ demand is smaller than the $\mathrm{N}$ supply (Cobo et al., 2002b; Lahti \& Kuikman, 2003). This release is affected by weather conditions, soil management, crop management practices (Fillery, 2001; Palm et al., 2001; Thompson \& Fillery, 2002) and residue properties. Legume mass characteristics of low $\mathrm{C} / \mathrm{N}$ ratio, the high concentration of soluble compounds and low lignin and polyphenol contents favours the rapid microbial degradation (Cobo et al., 2002a). On the other hand, grasses usually present the opposite characteristics and its use as green manures can reduce $\mathrm{N}$ losses, through temporary $\mathrm{N}$ immobilization during plant debris decomposition (Cobo et al., 2002a). In different climate regions, recommendations have been made for mixtures of green manure species whose residues are rapidly decomposed with species whose residues are slowly decomposed (Boddey et al., 1997; Clark et al., 1997a; 1997b; Vaughan \& Evanylo, 1998). Thus, intercropping legume and grass crops can result in a residue combination that could slow down $\mathrm{N}$ release and help to match nutrient supply with crop demand. The objective of this study was to evaluate the effects of green manure intercrop of sunnhemp and millet on the subsequent grain yield and $\mathrm{N}$ nutrition of maize crop.

\section{MATERIAL AND METHODS}

This experiment was carried out from 5 December 2001 to 5 April 2002 in Viçosa, MG, Brazil $\left(20^{\circ} 45^{\prime} \mathrm{S}, 42^{\circ} 51^{\prime} \mathrm{W}, 651 \mathrm{~m}\right.$ above sea level) on a loamy clay Dystric Cambisol (21\% sand, 30\% silt, $49 \%$ clay), with the following soil chemical characteristics $(0-20 \mathrm{~cm})$ before liming: $\mathrm{pH}$ 5.3; $\mathrm{Al}^{+3} 0.4$ cmolc kg ${ }^{-1} \mathrm{Ca}^{+2} 4.3 \mathrm{cmolc} \mathrm{kg}^{-1} ; \mathrm{Mg}^{+2} 1.1 \mathrm{cmolc} \mathrm{kg}^{-1}$; $\mathrm{K}+117 \mathrm{mg} \mathrm{kg}^{-1}$ and $\mathrm{P}$ available $93 \mathrm{mg} \mathrm{kg}^{-1}$ of soil and $16 \mathrm{~g} \mathrm{~kg}^{-1}$ of total soil C (Walkley Black, Allison 1965). The $\mathrm{KCl}$ extractor was used to determine the $\mathrm{Al}^{+3}$, $\mathrm{Ca}^{+2}$, and $\mathrm{Mg}^{+2}$ content, and the Mehlich-1 extractor was used to determine the $\mathrm{K}+$ and $\mathrm{P}$ content. For correction of $\mathrm{Al}^{+3}, 1,000 \mathrm{~kg} \mathrm{ha}^{-1}$ lime was applied 120 days before maize crop planting. Total rainfall during experimental period was $910 \mathrm{~mm}$, and the mean temperature was $22^{\circ} \mathrm{C}$.

The experiment was arranged in a randomized block, split plot design, with four replicates. The main plots were $48 \mathrm{~m}^{2}(12 \mathrm{~m} \times 4 \mathrm{~m})$ and the subplots 16 $\mathrm{m}^{2}(4 \mathrm{~m} \times 4 \mathrm{~m})$. The main plot treatments consisted of previous cultivation of the green manures sunnhemp, millet, intercrop sunnhemp + millet $(50 \%+$ $50 \%)$ and spontaneous weeds. The green manures were grown in parallel lines $0.25 \mathrm{~m}$ apart. The subplot treatments were $90 \mathrm{~kg} \mathrm{~N}^{-1}$ and control (without application of $\mathrm{N}$ fertilization to the maize crop). Nitrogen fertilizer was supplied as urea in two applications: $1 / 3$ at planting time and $2 / 3$ when the maize plants had 6 to 8 leaves.

The green manures were sown 68 days after planting (DAP) and the cut material was left on soil surface, covering the entire plot surface. The day of the mowing of the green manure, furrows $(0.2 \mathrm{~m}$ wide, $0.1 \mathrm{~m}$ deep) were open $1 \mathrm{~m}$ apart and maize (hybrid AG $1051^{\circledR}$ ) was manually sown in December 2001, using 10 seeds $/ \mathrm{m}$, thinned to 7 plants $/ \mathrm{m}$ at 20 DAP. Green manures residues were not incorporated and the furrows were open only on the maize planting lines. Maize crop in all subplots received $13 \mathrm{~kg} \mathrm{ha}^{-1}$ of $\mathrm{P}$ and 25 $\mathrm{kg} \mathrm{ha}^{-1}$ of $\mathrm{K}$, applied at planting. The experimental area was weeded at 22 DAP and weeds were left on soil surface. In green manure crops, the $\mathrm{C}$ content was determined by the Walkley-Black (Allison, 1965) method. The total-N content was determined by the sum of $\mathrm{NH}_{4}^{+}-\mathrm{N}$ and $\mathrm{NO}_{3}^{-}-\mathrm{N}$ forms. The ammonium content was determined by the Nessler colorimetric method (Jackson, 1958) after digestion in sulfuric acid. The Nessler method for ammonium is based on the complex formed by ammonium, mercurium and iodine $\left(\mathrm{Hg}_{2} \mathrm{O}\left(\mathrm{NH}_{2} \mathrm{I}\right)\right)$. The nitrate content was determined by the colorimetric method described by Cataldo et al. (1975). The nitrate is extracted in deionized water and the nitrate determination is based on the complex formed by nitration of salicylic acid.

$\mathrm{N}$ uptake was calculated by multiplying the total $\mathrm{N}$ content by the aboveground dry matter yield. The biological nitrogen fixation (BNF) by sunnhemp was determined by natural abundance of ${ }^{15} \mathrm{~N}$ technique $(\delta$ ${ }^{15} \mathrm{~N}$ ) (Shearer \& Kohl, 1986). Millet, Pannicum maximum and Bidens pilosa were the non-N fixing species. The BNF contribution to total $\mathrm{N}$ in sunnhemp plants was determined by the equation,

$\% B N F=\left(\frac{\delta^{15} N \text { nonfixing species }-\delta^{15} N \text { sunnhemp }}{\delta^{15} N \text { nonfixing species }-1}\right) \times 100$, 
One day after maize was planted, in each subplot seven samples of $100 \mathrm{~g}$ of fresh green manure residues ( $76 \%$ humidity) were placed on the soil surface besides the maize planting line. Each residue sample was covered with $30 \mathrm{~cm} \times 30 \mathrm{~cm}$ nylon screen, $4 \mathrm{~mm}$ mesh. The remaining dry matter of green manure residues was collected at 5, 10, 15, 30, 60, 90 and 120 DAP. The residue samples were dried, weighted, grounded and analyzed for $\mathrm{N}$ content. Decomposition kinetic was calculated by the simple exponential model described by Thomas \& Asakawa (1993), according to the following expression: $\mathrm{Y}=\mathrm{Y}_{0} \mathrm{e}^{-\mathrm{kt}}$, where $\mathrm{Y}$ is the remaining dry matter or nutrient amount after a time period " $\mathrm{t}$ ", in days, " $\mathrm{k}$ " is the decomposition rate constant and $\mathrm{Y}_{0}$ is the total dry matter and nutrient at the beginning of the experiment. Half life of crop residues can be calculated by the equation $t_{1 / 2}=\ln (2) / k$, where $t_{1 / 2}$ is the time required to reduce the nutrient content or the crop residue mass to half the initial value.

At harvest time (130 DAP), maize plants sown in $2 \mathrm{~m}^{2}$ of the central row were cut at soil surface and weighed to determine dry matter yield and grain yield (14\% of humidity). After drying, the samples were grounded to $<0.85 \mathrm{~mm}$, and the total $\mathrm{N}$ content was determined by the sum of $\mathrm{NH}_{4}^{+}-\mathrm{N}$ and $\mathrm{NO}_{3}{ }^{-} \mathrm{N}$ forms, determined according to the methodology of Jackson (1958) and Cataldo et al. (1975), respectively. Nitrogen accumulation by maize crop was calculated based on the $\mathrm{N}$ content and dry matter of the grain and stover. The presence of BNF-N in the maize crop was determined by the ${ }^{15} \mathrm{~N}$ natural abundance technique $(\delta$ ${ }^{15} \mathrm{~N}$ ) (Shearer \& Kohl, 1986). The proportion of $\mathrm{N}$ in the maize crop derived from BNF in green manures was determined by the equation:

$\% B N F-N=\left(\frac{\delta^{15} N(N-\text { fertilized maize })-\delta^{15} N(\text { maize after green manure })}{\delta^{15} N(N-\text { fertilized maize })}\right) \times 100$

The data were submitted to Analysis of Variance (ANOVA) using the Statistical and Genetic Analy- sis System (SAEG) version 8.0 using the $\mathrm{F}$ test and the Tukey test, both at $P<0.05$.

\section{RESULTS}

\section{Green manure production and composition and residue decomposition kinetics}

Sunnhemp monocrop presented the highest N accumulation and biological fixation of $\mathrm{N}_{2}$ (Table 1). No significant differences were observed between sunnhemp and millet monocrops or intercropped in relation to the decomposition rate (Figure 1a, Table 2). The weed residues had a faster decomposition rate (Figure 1a), resulting in the lowest t 1/2 (Table 2). The $\mathrm{N}$ release kinetics is presented on Figure 1b. The $\mathrm{N}$ release rate of the sunnhemp+millet residue was slower than that of sunnhemp monocrop and faster than that of millet alone (Table 2).

\section{Maize production}

In the absence of fertilizer $\mathrm{N}$, the highest grain yield was obtained after sunnhemp+millet crop, although it was not different from yields obtained after sunnhemp and weed (Table 3). In the absence of $\mathrm{N}$ fertilization, maize grown after sunnhemp+millet had the highest stover dry matter production, which was different from sunnhemp alone (Table 3 ). In the presence of $\mathrm{N}$ fertilization $\left(90 \mathrm{~kg} \mathrm{~N} \mathrm{ha}^{-1}\right)$ there were no statistically significant differences (Table 3 ), however, maize grain yield was significant higher in the presence of sunnhemp residues, alone or intercropped with millet, when fertilized with $90 \mathrm{~kg} \mathrm{~N} \mathrm{ha}^{-1}$.

The orthogonal contrasts between the effects of weeds $+90 \mathrm{~kg} \mathrm{~N} \mathrm{ha}^{-1}$ and the green manure crop without $\mathrm{N}$-fertilizer application are presented on Table 5. Aboveground dry matter and grain yield were reduced by previous millet cultivation. The previous cultivation of sunnhemp+millet mixture resulted in both grain yield and stover dry matter yield higher than the control treatment.

Table 1 - Carbon: nitrogen ratio, dry matter yield, $\mathrm{N}$ content and $\mathrm{N}$ accumulated aboveground in different green manures and biological fixation of $\mathrm{N}_{2}$ (BNF) of sunnhemp plants cut 68 days after planting.

\begin{tabular}{|c|c|c|c|c|c|c|}
\hline Green manure & $\mathrm{C}: \mathrm{N}$ & Dry matter yield & $\mathrm{N}$ content & Accumulated $\mathrm{N}$ & \multicolumn{2}{|c|}{$\mathrm{N}-\mathrm{BNF}$} \\
\hline & & $\mathrm{Mg} \mathrm{ha}^{-1}$ & $\mathrm{~g} \mathrm{~kg}^{-1}$ & $\mathrm{~kg} \mathrm{ha}^{-1}$ & $\%$ & $\mathrm{~kg} \mathrm{ha}^{-1}$ \\
\hline Sunnhemp & 13 & $9.3 \mathrm{a}$ & $32.7 \mathrm{a}$ & $305 \mathrm{a}$ & 57.0 & $174 \mathrm{a}$ \\
\hline Millet & 30 & $7.1 \mathrm{ab}$ & $13.9 \mathrm{~b}$ & $97 \mathrm{c}$ & - & - \\
\hline Sunnhemp + millet* & 15 & $8.0 \mathrm{ab}$ & $27.1 \mathrm{a}$ & $218 b$ & 61.1 & $89 \mathrm{~b}$ \\
\hline Spontaneous weeds & 15 & $4.5 \mathrm{~b}$ & $28.4 \mathrm{a}$ & $126 \mathrm{c}$ & - & - \\
\hline
\end{tabular}

In each column, values followed by same letter do not differ (Tukey test $P \geq 0.05$ ).

*In intercropping, the $\mathrm{N}$ content of sunnhemp was $26.9 \mathrm{~g} \mathrm{~kg}^{-1}$ and $20.5 \mathrm{~g} \mathrm{~kg}^{-1}$ of millet. The $\mathrm{N}$ accumulated by sunnhemp was $144 \mathrm{~kg}$ ha${ }^{1}$ and by millet, $74 \mathrm{~kg} \mathrm{ha}^{-1}$.

$\%$ : percentage of total $\mathrm{N}$ content derived from $\mathrm{BNF}$ 

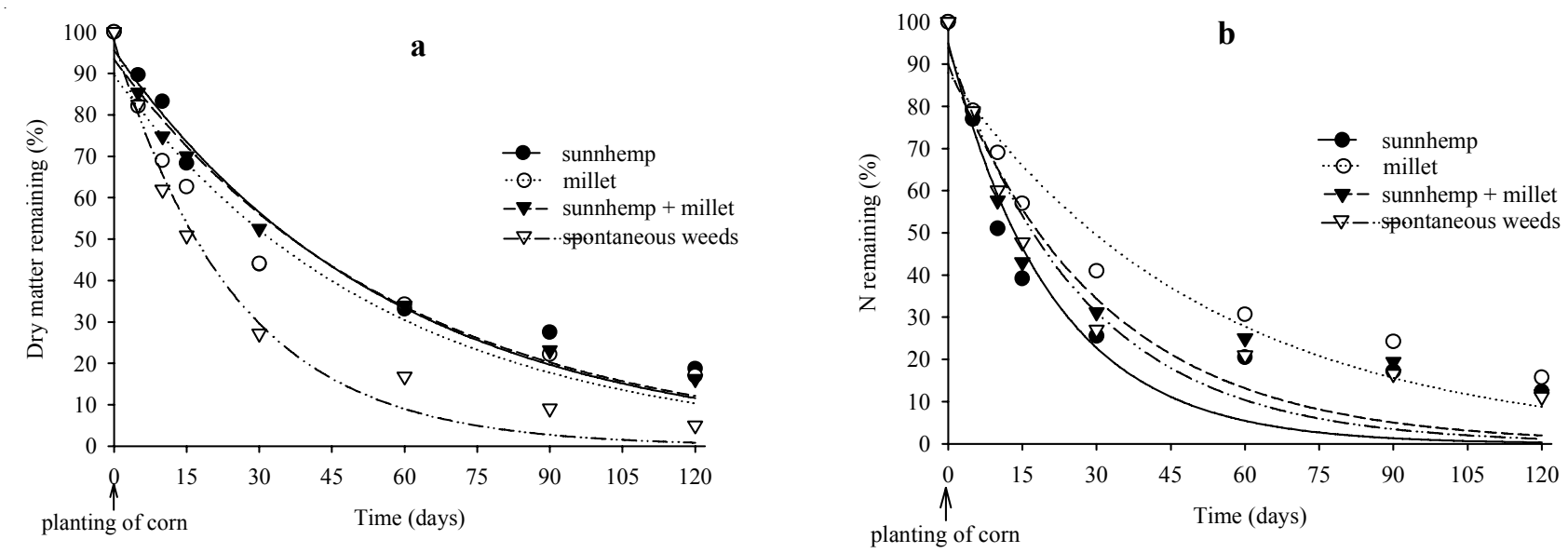

Figure 1 - Decomposition (Figure 1a) and N release (Figure 1b) of green manure residues between December 5, 2001 and April 5,2002.

Table 2 - Regression parameters of dry matter decomposition and $\mathrm{N}$ release with the respective rate constants of decomposition $(\mathrm{k})$ and time of half life $\left(\mathrm{t}_{1 / 2}\right)$ of different green manure crop residues evaluated between December 5, 2001 and April $5,2002 . \hat{Y}=$ remaining dry matter or $\mathrm{N}$ (\% of initial amount $)$ after a time period $\mathrm{X},(\mathrm{X}=$ days $)$.

\begin{tabular}{lccc}
\hline Green manure & \multicolumn{1}{c}{ Equation } & Half life $\left(\mathrm{t}_{1 / 2}\right)$ & Coefficient of determination \\
\hline & \multicolumn{1}{c}{ Parameters of dry matter decomposition } & $\mathrm{r}^{2}$ \\
Sunnhemp & $\hat{\mathrm{Y}}=95.5886 \mathrm{e}^{(-0.0176 \mathrm{X})}$ & $39 \mathrm{a}$ & 0.95 \\
Millet & $\hat{\mathrm{Y}}=89.4711 \mathrm{e}^{(-0.0180 \mathrm{X})}$ & $39 \mathrm{a}$ & 0.92 \\
Sunnhemp+Millet & $\hat{\mathrm{Y}}=93.4425 \mathrm{e}^{(-0.0170 \mathrm{X})}$ & $41 \mathrm{a}$ & 0.97 \\
Spontaneous weeds & $\hat{\mathrm{Y}}=95.9312 \mathrm{e}^{(-0.0394 \mathrm{X})}$ & $18 \mathrm{~b}$ & 0.95 \\
\hline & & Parameters of N release & \\
Sunnhemp & $\hat{\mathrm{Y}}=94.8307 \mathrm{e}^{(-0.0474 \mathrm{X})}$ & $15 \mathrm{~d}$ & 0.93 \\
Millet & $\hat{\mathrm{Y}}=87.9444 \mathrm{e}^{(-0.0192 \mathrm{X})}$ & $36 \mathrm{a}$ & 0.90 \\
Sunnhemp+Millet & $\hat{\mathrm{Y}}=89.7354 \mathrm{e}^{(-0.0318 \mathrm{X})}$ & $22 \mathrm{~b}$ & 0.90 \\
Spontaneous weeds & $\hat{\mathrm{Y}}=93.8539 \mathrm{e}^{(-0.0376 \mathrm{X})}$ & $19 \mathrm{c}$ & 0.95 \\
\hline
\end{tabular}

Half life $\left(\mathrm{t}_{1 / 2}\right)$ : means followed by same letter do not differ (Tukey test $P \geq 0.05$ ).

Table 3 - Parameters of maize performance cropped after different green manures treatments, with and without $\mathrm{N}$ fertilizer application.

\begin{tabular}{|c|c|c|c|c|}
\hline \multirow{2}{*}{$\begin{array}{l}\text { Pre-cropping of green } \\
\text { manure }\end{array}$} & \multicolumn{2}{|c|}{ Without $\mathrm{N}$ fertilization } & \multicolumn{2}{|c|}{ With $\mathrm{N}$ fertilization $\left(90 \mathrm{~kg} \mathrm{ha}^{-1}\right)$} \\
\hline & Stover dry matter & Grain yield & Stover dry matter & Grain yield \\
\hline & - - & 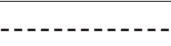 & $\mathrm{ha}^{-1} \ldots \ldots-\ldots$ & $-\cdots-1$ \\
\hline Sunnhemp & $13.4 \mathrm{ab}$ & $6.6 \mathrm{ab}$ & $18.2 \mathrm{a}$ & $10.8 \mathrm{a}$ \\
\hline Millet & $9.0 \mathrm{~b}$ & $4.3 \mathrm{~b}$ & $14.7 \mathrm{a}$ & $6.1 \mathrm{~b}$ \\
\hline Sunnhemp+Millet & $17.5 \mathrm{a}$ & $8.4 \mathrm{a}$ & $17.5 \mathrm{a}$ & $10.3 \mathrm{a}$ \\
\hline Spontaneous weeds & $11.2 \mathrm{~b}$ & $6.0 \mathrm{ab}$ & $13.6 \mathrm{a}$ & $6.6 \mathrm{~b}$ \\
\hline C. V $(\%)$ & 13.0 & 15.3 & 13.0 & 15.3 \\
\hline
\end{tabular}

In each column, means followed by same letter do not differ (Tukey test, $P \geq 0.05$ ).

\section{Maize $N$ uptake}

Without N-fertilizer application, maize crop after sunnhemp + millet resulted in a greater accumulation of $\mathrm{N}$ by the grain, mainly due to higher grain yield, since the $\mathrm{N}$ content of grain was similar in all the treatments in this study (Table 4). The presence of sunnhemp (as monocrop or intercropped with millet) increased the total $\mathrm{N}$ accumulated by grain in maize plants grown on plots fertilized with $90 \mathrm{~kg} \mathrm{~N}^{-1}$ (Table 4).

The $\mathrm{N}$ content in aboveground maize plant cultivated after the green manure treatments was similar 
to the weeds $+90 \mathrm{~kg} \mathrm{~N}^{-1}$ treatment. However, the preceding cultivation of sunnhemp+millet mixture resulted in larger $\mathrm{N}$ accumulation in maize aboveground biomass than the supply of $90 \mathrm{~kg} \mathrm{~N} \mathrm{ha}^{-1}$ after weeds presence (Table 5).

\section{Utilization of green manure fixed $\mathbf{N}$}

In the absence of $\mathrm{N}$-fertilizer, maize cropped after sunnhemp monocrop presented in the aboveground biomass $25 \mathrm{~kg} \mathrm{ha}^{-1}$ of $\mathrm{N}$ derived from BNF, corresponding to $15 \%$ of the initial $174 \mathrm{~kg} \mathrm{ha}^{-1}$ of BNF-N present in the sunnhemp aboveground biomass (Table 6). Nevertheless, when cropped after sunnhemp+millet intercropping, maize aboveground biomass accumulated $22 \mathrm{~kg} \mathrm{ha}^{-1}$ of BNF-N, corre- sponding to $24 \%$ of the $89 \mathrm{~kg} \mathrm{ha}^{-1}$ BNF-N initially present in the intercropping aboveground biomass (Table 6).

\section{DISCUSSION}

The $\mathrm{N}$ release rates were higher than the mass decomposition rates in this study, this difference is consistent with similar studies (Mwiinga et al., 1994; Cobo et al., 2002a). The warm and rainy climate during the experiment favoured the rapid decomposition of the residues (Fillery, 2001). The high N content and low $\mathrm{C}: \mathrm{N}$ ratio also account for both high decomposition and high net $\mathrm{N}$ release (Fillery, 2001; Cobo et al., $2002 \mathrm{~b}$ ) of sunnhemp residues. Although it was cut in

Table 4 - Total $\mathrm{N}$ content and $\mathrm{N}$ accumulated by maize grown after different green manure treatments, with and without $\mathrm{N}$ fertilizer application.

\begin{tabular}{|c|c|c|c|c|c|c|c|c|}
\hline \multirow{3}{*}{ Pre-cropping } & \multicolumn{4}{|c|}{ With $\mathrm{N}$ fertilization $\left(90 \mathrm{~kg} \mathrm{ha}^{-1}\right)$} & \multicolumn{4}{|c|}{ Without $\mathrm{N}$ fertilization } \\
\hline & \multicolumn{2}{|c|}{$\mathrm{N}$ content } & \multicolumn{2}{|c|}{$\mathrm{N}$ accumulated } & \multicolumn{2}{|c|}{$\mathrm{N}$ content } & \multicolumn{2}{|c|}{$\mathrm{N}$ accumulated } \\
\hline & Grain & Stover & Grain & Stover & Grain & Stover & Grain & Stover \\
\hline & \multicolumn{2}{|c|}{ 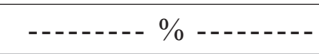 } & \multicolumn{2}{|c|}{-.... kg ha-1 $\ldots$} & \multicolumn{2}{|c|}{ - } & \multicolumn{2}{|c|}{-.... kg ha ${ }^{-1} \ldots \ldots$} \\
\hline Sunnhemp & $1.57 \mathrm{a}$ & $0.81 \mathrm{a}$ & 169 a & 149 a & $1.37 \mathrm{a}$ & $0.63 \mathrm{a}$ & $91 \mathrm{ab}$ & 82 a \\
\hline Millet & $1.44 \mathrm{a}$ & $0.73 \mathrm{a}$ & $90 \mathrm{~b}$ & $107 \mathrm{a}$ & $1.56 \mathrm{a}$ & $0.77 \mathrm{a}$ & $68 \mathrm{~b}$ & $69 \mathrm{a}$ \\
\hline Sunnhemp+Millet & $1.64 \mathrm{a}$ & $0.71 \mathrm{a}$ & 169 a & 129 a & $1.59 \mathrm{a}$ & $0.85 \mathrm{a}$ & $135 \mathrm{a}$ & $150 \mathrm{a}$ \\
\hline Spontaneous weeds & $1.57 \mathrm{a}$ & $0.69 \mathrm{a}$ & $102 \mathrm{~b}$ & 93 a & $1.54 \mathrm{a}$ & $0.71 \mathrm{a}$ & $94 \mathrm{ab}$ & $78 \mathrm{a}$ \\
\hline C. V (\%) & 6.9 & 29.1 & 17.8 & 37.8 & 6.9 & 29.1 & 17.8 & 37.8 \\
\hline
\end{tabular}

In each column, means followed by same letter do not differ (Tukey test, $P \geq 0.05$ ).

Table 5 - Parameters of maize performance cropped after different green manure without $\mathrm{N}$-fertilizer versus maize crop cropped after spontaneous weeds and fertilized with $90 \mathrm{~kg} \mathrm{~N} \mathrm{ha}^{-1}$.

\begin{tabular}{|c|c|c|c|c|c|c|}
\hline \multirow{2}{*}{ Pre-cropping } & \multirow{2}{*}{ Stover dry matter } & \multirow{2}{*}{ Grain yield } & \multicolumn{2}{|c|}{$\mathrm{N}$ content } & \multicolumn{2}{|c|}{$\mathrm{N}$ accumulated } \\
\hline & & & grain & stover & grain & stover \\
\hline & $\mathrm{Mg} \mathrm{ha}^{-1}$ & $\mathrm{Mg} \mathrm{ha}^{-1}$ & $-\cdots-\cdots$ & $-\cdots--$ & -...- $\mathrm{kg} \mathrm{ha}^{-1}$ & $1-\ldots-$ \\
\hline Sunnhemp & $13.4^{\mathrm{ns}}$ & $6.6^{\mathrm{ns}}$ & $1.37 *$ & $0.63^{\mathrm{ns}}$ & $91^{\mathrm{ns}}$ & $82^{\text {ns }}$ \\
\hline Millet & $9.0 *$ & $4.3^{*}$ & $1.56^{\mathrm{ns}}$ & $0.77^{\mathrm{ns}}$ & $68 *$ & $69^{\text {ns }}$ \\
\hline Sunnhemp+Millet & $17.5^{*}$ & $8.4^{*}$ & $1.59^{\mathrm{ns}}$ & $0.85^{\text {ns }}$ & $135^{*}$ & $150 *$ \\
\hline Spontaneous weeds & $11.2^{\mathrm{ns}}$ & $5.9^{\mathrm{ns}}$ & $1.54^{\mathrm{ns}}$ & $0.71^{\text {ns }}$ & $94^{\text {ns }}$ & $78^{\text {ns }}$ \\
\hline Spontaneous weeds $+90 \mathrm{~kg} \mathrm{~N} \mathrm{ha}^{-1}$ & 13.6 & 6.6 & 1.57 & 0.69 & 103 & 94 \\
\hline
\end{tabular}

In each column *indicates significant difference and ${ }^{\text {ns }}$ indicates not significant differences $(\mathrm{t}$ test $P<0.05)$.

Table 6 - Accumulation, content and utilization of BNF-N by maize cropped without N-fertilizer, after sunnhemp monocrop or sunnhemp+millet intercropping.

\begin{tabular}{|c|c|c|c|c|c|c|}
\hline & \multicolumn{3}{|c|}{$\mathrm{BNF}-\mathrm{N}$ in maize } & \multicolumn{2}{|c|}{$\mathrm{BNF}-\mathrm{N}$ in maize } & \multirow{2}{*}{$\begin{array}{c}\text { Utilization of BNF-N by maize } \\
\text { Above-ground }\end{array}$} \\
\hline & Grain & Stover & Above-ground & Grain & Stover & \\
\hline & \multicolumn{3}{|c|}{ - } & \multicolumn{2}{|c|}{--- \% maize-N --- } & - \\
\hline Sunnhemp & $13.8 \mathrm{a}$ & $11.4 \mathrm{a}$ & $25.2 \mathrm{a}$ & $15.2 \mathrm{a}$ & $13.8 \mathrm{a}$ & $14.5 \mathrm{~b}$ \\
\hline Sunnhemp+Millet & $13.2 \mathrm{a}$ & $8.1 \mathrm{a}$ & $21.3 \mathrm{a}$ & $9.8 \mathrm{~b}$ & $8.4 \mathrm{a}$ & $23.9 \mathrm{a}$ \\
\hline
\end{tabular}

In each column, means followed by same letter do not differ (F test, $P \geq 0.05$ ). Original data of BNF-N in green manures are presented in Table 1 and data of maize grain and stover yield and $\mathrm{N}$ content are presented in Tables 3 and 4. 
an early stage, millet presented low $\mathrm{N}$ content and higher $\mathrm{C}: \mathrm{N}$ ratio, resulting in less $\mathrm{N}$ release (Fillery, 2001; Thompson \& Fillery, 2002) or even in reimmobilisation of mineralised $\mathrm{N}$ from soil organic matter (Thompson \& Fillery, 2002). The intermediate rates of residue decay and $\mathrm{N}$ release rates found for the sunnhemp+millet mixture reflects the joint contribution of both residues characteristics.

Without $\mathrm{N}$-fertilizer, maize crop grown after millet cultivation showed a grain yield $28 \%$ lower than maize crop grown after weed residues. Since K and $\mathrm{P}$ were supplied, in spite of the high availability values shown by soil analysis, the result is probably due to $\mathrm{N}$ immobilization by the grass residues during decomposition (Thompson \& Fillery, 2002) as found by Clark et al. (1997b) and Vaughan \& Evanylo (1998) on maize crop cultivated after rye cover.

In the presence of $\mathrm{N}$-fertilizer, sunnhemp intercropped with millet resulted in maize grain yield 56 and $67 \%$ higher than maize crop grown after weeds and millet, respectively, emphasizing the importance of green manure legumes for increasing grain yield of maize crop. A similar result was obtained when maize was cropped following a hairy vetch and hairy vetch + rye mixture, when compared to rye cover or nocover (Clark et al., 1997b). Sunnhemp used as green manure could account for an input of $150 \mathrm{~kg} \mathrm{~N} \mathrm{ha}^{-1}$ thus explaining the higher maize grain yield (3.3 Mg $\mathrm{ha}^{-1}$ ) as compared to the control treatment without sunnhemp (1.0 $\mathrm{Mg} \mathrm{ha}^{-1}$ ) obtained by Ramos et al. (2001).

In the absence of $\mathrm{N}$-fertilizer, the higher input of BNF-N from sunnhemp monocrop did not result in its higher utilization by the following maize crop. The pre crop of sunnhemp + millet resulted in both higher maize stover dry matter and $\mathrm{N}$ accumulated in the grain and grain yield, although intercropped sunnhemp + millet accumulated a lower amount of $\mathrm{N}$ than the sunnhemp monocrop. The grass-legume mixture residue probably presented a $\mathrm{N}$ release kinetic more synchronized with maize requirements than the legume or grass monocrop and this behavior at least partially accounted for improved maize yield, even dispensing $\mathrm{N}$-fertilizer. The results reinforce the findings of reduced rice yield improvement by higher quality green manures reported by Cobo et al. (2002b) and confirm their suggestion that green manures that release $\mathrm{N}$ slowly would result in high $\mathrm{N}$ uptake by following crops under tropical conditions. The timing of $\mathrm{N}$ availability was partially responsible for the higher maize yield after hairy vetch cover and hairy vetch+rye cover found by Clark et al. (1997b) and Vaughan \& Evanylo (1998), although the better timing of cover crop kill were different in those experiments. Indeed, sunnhemp residues released around $150 \mathrm{~kg} \mathrm{~N} h a^{-1}$ in the first 15 days. Similar N release have been reported by Azam et al. (1985), Harris et al. (1994) and Scivittaro et al. (2000), who reported that only 5 to $14 \%$ of the leguminous-N was recovered from maize biomass

The results suggest a synergistic effect of both sunnhemp and $\mathrm{N}$ fertilization on $\mathrm{N}$ accumulation by grains as related by Clark et al. (1997a) and Rees et al. (1993). A similar result was observed by Scivittaro et al. (2000), who report that the utilization of $\mathrm{N}$ fertilizer by maize increased from $39 \%$ under control treatment to $47 \%$, in the presence of velvet bean $(\mathrm{Mu}$ cuna aterrima) residues used as green manure. This enhanced nitrogen nutrition of the maize crop by sunnhemp residue decomposition has likely contributed to increased grain yield.

Thus, the utilization of the BNF-N initially present in green manures by maize was $65 \%$ higher after sunnhemp+millet monocrop than after sunnhemp monocrop, as a result of the already discussed $\mathrm{N}$ release patterns. The results probably underestimate the amount of total BNF-N recovered from the legume residues, because part of this $\mathrm{N}$ can also be accumulated by maize roots (Azam et al., $1995)$. Besides, the $15 \mathrm{~N}$ released by legume residue decay could be exchanged for $14 \mathrm{~N}$ present in microbial biomass, reducing the $15 \mathrm{~N}$ recovery on maize plants (Stevens et al., 2005) and the largest proportion of $\mathrm{N}$ (circa $50 \%$ ) of legume plants became soilbound (Harris \& Hesterman, 1990). Nevertheless, under tropical conditions significant amount of $\mathrm{N}$ released when crops do not need it is probably lost through leaching and volatilization. Up to $14 \%$ of mass $\mathrm{N}$ can be volatilized when the legume residue is not incorporated into soil (Janzen \& McGinn, 1991). In this experiment, the green manure was not incorporated into soil. Although data on $\mathrm{N}$ volatilization were not collected, it is possible that volatilization losses may have contributed to the lower utilization of BNF-N of sunnhemp residues by maize crop. Intercropping legume and cereals is a promising biological strategy to achieve and to keep $\mathrm{N}$ into the production system under tropical conditions.

\section{ACKNOWLEDGEMENT}

The research was partially funded by CAPES which granted a Graduate scholarship.

\section{REFERENCES}

ALLISSON, L.E. Organic carbon. In: BLACK, C.A. (Ed). Methods of soil analysis. Madison: ASA. 1965. p.1367-1379. (Agronomy Series, 9). 
AZAM, F.; MALIK, K.A.; SAJJAD, M.I. Transformation in soil and availability to plants of $15 \mathrm{~N}$ applied as inorganic fertilizer and legume residues. Plant and Soil, v.86, p.3-13, 1985.

AZAM, F.; MULVANEY, R.L.; SIMMONS, F.W.; Effects of ammonium and nitrate on mineralization of nitrogen from leguminous residues. Biology and Fertility of Soils, v.20, p.49-52, 1995

BODDEY, R.M.; SÁ, J.C.M.; ALVES, B.J.R.; URQUIAGA, S. S. The contribution of biological nitrogen fixation for sustainable agricultural systems in the tropics. Soil Biology and Biochemistry, v.29, p.787-799, 1997.

CATALDO, D.A.; AARÓN, M.; SCHARDER, M.; YOUNGS, V.L. Rapid colorimetric determination of nitrate in plant tissue by nitrification of salicylic acid. Communications in Soil Science and Plant Analysis, v.6, p.71-81, 1975.

CLARK, A.J.; DECKER, A.M.; MEISINGER, J.J.; MCINTOSH, M.S. Kill date of rye, and a vetch-rye mixture: I. Cover crop and maize nitrogen. Agronomy Journal, v.89, p.427-434, $1997 \mathrm{a}$.

CLARK, A.J.; DECKER, A.M.; MEISINGER, J.J.; MCINTOSH, M.S. Kill date of rye, and a vetch-rye mixture. II. Soil moisture and maize yield. Agronomy Journal, v.89, p.434-441, 1997b.

COBO, J.G.; BARRIOS, E.; KASS, D.C.L.; THOMAS, R.J. Decomposition and nutrient release by green manures in a tropical hillside agroecosystem. Plant and Soil, v.240, p.331342, 2002a.

COBO, J.G.; BARRIOS, E.; KASS, D.C.L.; THOMAS, R.J. Nitrogen mineralization and crop uptake from surface-applied leaves of green manure species on a tropical volcanic-ash soil. Biology and Fertility of Soils, v.36, p.87-92, 2002b.

FILLERY, I.R.P. The fate of biologically fixed nitrogen in legumebased dryland farming system: a review. Australian Journal of Experimental Agriculture, v.41, p.361-381, 2001.

HARRIS, G.H.; HESTERMAN, O.B. Quantifying the nitrogen contribution from alfalfa to soil and two succeeding crops using Nitrogen-15. Agronomy Journal, v.82, p.129-134, 1990.

HARRIS, G.H.; HESTERMAN, O.B.; PAUL, E.A.; PETERS, S.E.; JANKE, R.R. Fate of legume and fertilizer nitrogen-15 in a long term cropping systems experiment. Agronomy Journal, v.86, p.910-915, 1994.

JACKSON, M.L.; Nitrogen determinations for soil and plant tissue. In: JACKSON, M.L. (Ed). Soil chemical analysis. New Jersey: Prentice Hall, 1958. p.183-204.

JANZEN, H.H.; McGINN, S.M. Volatile loss of nitrogen during decomposition of legume green manure. Soil Biology and Biochemistry, v.23, p.291-297, 1991.

LAHTI, T.; KUIKMAN, P.J. The effect of delaying incorporation of green manure crop on $\mathrm{N}$ mineralization and spring wheat (Triticum aestivum L.) performance. Nutrient Cycling in Agroecosystems, v.65, p.265-280, 2003.
MWIINGA, R.D.; KWESIGA, F.R.; KAMARA, C.S. Decomposition of leaves of six multipurpose tree species in Chipata, Zambia. Forest Ecology Management, v.64, p.209-216, 1994.

PALM, C.A.; GACHENGO, C.N.; DELVE, R.J.; CADISH, G.; GILLER, K.E. Organic inputs for soil fertility management in tropical agroecosystems: application of an organic resource database. Agriculture, Ecosystem and Environment, v.83, p.27-42, 2001.

RAMOS, M.G.; VILLATORO, M.A.A.; URQUIAGA, S.; ALVES, B.J.R.; BODDEY, R.M. Quantification of the contribution of biological nitrogen fixation to tropical green manure crops and the residual benefit to a subsequent maize crop using ${ }^{15} \mathrm{~N}$-isotope techniques. Journal of Biotechnology, v.91, p.105-115, 2001.

REES, R.M.; YAN, L.; FERGUSON, M. The release and plant uptake of nitrogen from some plant and animal manures Biology and Fertility of Soils, v.15, p.285-293, 1993.

SCIVITTARO, W.B.; MURAOKA, T.; BOARETTO, A.E.; TRIVELIN, P.C.O. Utilização de nitrogênio de adubos verde e mineral pelo milho. Revista Brasileira de Ciência do Solo, v.24, p.917-926, 2000.

SHEARER, G.; KOHL, D.H. $\mathrm{N}_{2}$-fixation in field settings: estimations based on natural ${ }^{15} \mathrm{~N}$ abundance. Australian Journal of Plant Physiology, v.13, p.699-756, 1986.

STEVENS, W.B.; HOEFT, R.G.; MULVANEY, R.L. Fate of nitrogen.-15 in a long-term nitrogen rate study: II. Nitrogen uptake efficiency. Agronomy Journal, v.97, p.1046-1053, 2005.

THOMAS, R.J.; ASAKAWA, N.M. Decomposition of leaf litter tropical forage grasses and legumes. Soil Biology and Biochemistry, v.25, p.1351-1361, 1993.

THOMPSON, R.B.; FILLERY, I.R.P. Mineralization of nitrogen contained in mature subterranean clover, capeweed and annual ryegrass, and subsequent nitrogen use by wheat in dryland farming systems in southern Australia. Australian Journal of Soil Research, v.40, p. 299-315, 2002.

TIAN, G.; KANG, B.T.; BRUSSARD, L. Biological effects of plants residues with contrasting chemical composition under humid tropical conditions - decomposition and nutrient release. Soil Biology and Biochemistry, v.24, p.1051-1060, 1992.

VAUGHAN, J.D.; EVANYLO, G.K. Maize response to cover crop species, spring desiccation time, and residue management. Agronomy Journal, v.90, p.536-544, 1998.

Received October 06, 2005

Accepted July 22, 2006 